\title{
Waste Coconut Shell as a Partial Replacement of Coarse Aggregate in Concrete Mix - An Experimental Study
}

\author{
Yogesh Narayan Sonawane ${ }^{1}$, Chetan Jaiprakash Chitte ${ }^{2}$ \\ ${ }^{1,2}$ Assistant Professor, R. C. Patel Institute of Technology, Shirpur, Maharashtra, India
}

\begin{abstract}
In construction industry the rising cost of construction material is the great factor. The prices of building materials are rising day by day. Therefore this is a most priority of all human being to encourage or research on sustainable material which will help to use such waste material as construction material with less cost and safety of structure. The course aggregate is the main constituent of concrete mix, hence in this paper we used coconut shell as a coarse aggregate has been discussed based on the results obtained from test results. The use of coconut shell can also help the prevention of the environment. The paper aims at analyzing compressive strength of concrete (M20-1:1.5:3) produced using coconut shell as substitute for conventional coarse aggregate with $0 \%, 25 \%, 50 \%, 100 \%$ partial replacement. Three sample cubes are prepared for M20 grade concrete mix for each case another aim of this paper is to spread awareness about use of coconut shell as construction material in civil engineering.
\end{abstract}

Keywords: Construction material, coconut shell, compressive strength of coconut shell, Coconut shell concrete, Waste Utilization

\section{Introduction}

Concrete is the vital civil engineering material. Its manufacturing involves utilization of ingredients like cement, sand, aggregates, water and required admixtures. Demand of construction material is increased due to infrastructural development across the world. Now time has come to think of some alternative materials for sustainable use in concrete mix. Day by day mount and type of waste materials has increased accordingly creating environmental issues. [1] Coconut is grown in more than 93 countries. South East Asia is regarded as the origin of coconut. India is the third largest, having cultivation on an area of about 1.78 million hectares. [8] Coconut shell is one of the waste material can also be used as a aggregate in concrete due to some reasons like large scale cultivation of coconut in coastal region of India including Keral, Andhra Pradesh, Goa, Kokan, etc. due to tough made tissue, shell is not decomposed easily and remain as solid waste for years.[1]

\section{Coconut shell as coarse aggregate}

The concrete obtained using Coconut Shell aggregates satisfies the minimum necessities of concrete. Coconut Shell concrete has superior workability because of the smooth surface on one side of the shells. The impact resistance of Coconut Shell concrete is high when compared with conventional concrete. Moisture retaining and water absorbing capacity of Coconut Shell are more compared to conventional aggregate. The amount of cement content may be more when Coconut Shell are used as an aggregate in the production of concrete compared to conventional aggregate concrete. The presence of sugar in the CS as long as it is not in a free sugar form, will not affect the setting and strength of concrete. It is found that wood based materials, being hard and of organic[10]

\section{Intention}

To prove the coconut shell concretes which are lightweight and can be use as an economical civil engineering material

\section{Research Material and testing}

\subsection{Materials}

Research material are cement, natural fine aggregate , coarse aggregate, water and coconut shell.

\subsection{Coconut Shell}

Coconut shell is obtained from temples etc. they were sun dried for minimum 1 month before using crushed manually. The particle size of the coconut shell range from $5 \mathrm{~mm}$ to $20 \mathrm{~mm}$. Cement- Ordinary Portland cement of 53 grade conforming to Indian Standard IS 12269-1987 9 was used throughout the experimental program.

\subsection{Fine Aggregate}

Naturally available fine aggregate from Tapi River

\subsection{Coarse Aggregate}

Crushed hard basalt chips of maximum size $20 \mathrm{~mm}$ were used in the concrete mixes. The bulk density of aggregate was $1545 \mathrm{~kg} / \mathrm{m} 3$ and specific gravity was found to be 2.77

\subsection{Water}

Potable water conforming to IS 456-2000 11 was used for casting and curing 


\section{International Journal of Science and Research (IJSR) \\ ISSN (Online): 2319-7064}

Index Copernicus Value (2013): 6.14 | Impact Factor (2014): 5.611

\subsection{Testing Methodology}

Test is carried out for finding compressive strength by using following experimental procedure.

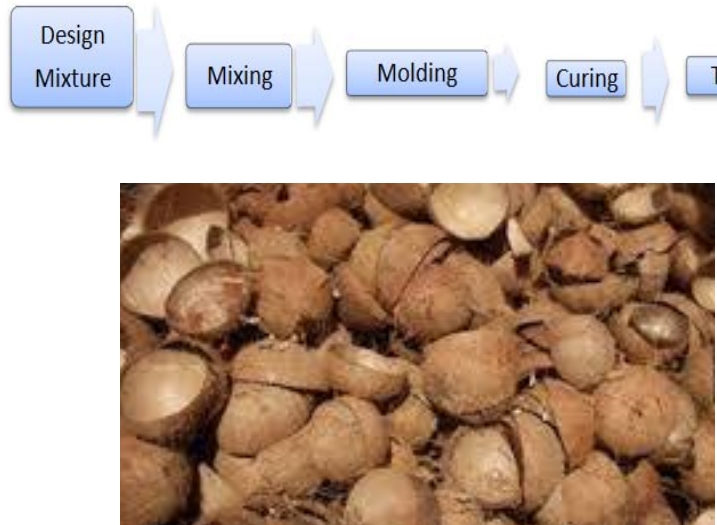

Figure 1: Coconut shells before cutting

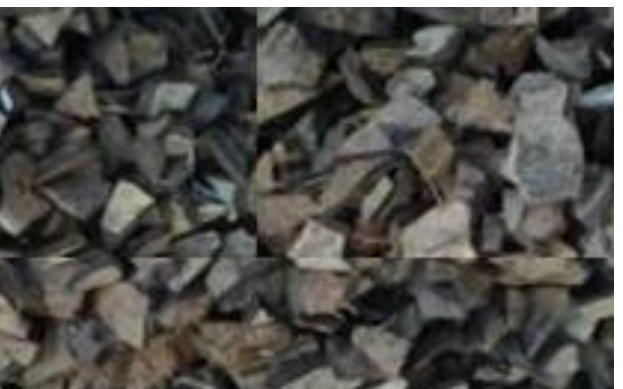

Figure 2: Coconut shells after cutting

\section{Concrete Mix Design}

Mix design is the process of selecting appropriate ingredients of concrete and determining their qualified amounts with the objective of producing a concrete of the compulsory strength, durability and workability as economical as possible.

\subsection{Factor to be considered for mix design}

1)The grade designation giving the characteristics requirement of concrete.

2)The type of cement influences the rate of development of compressive strength of concrete.

3)Maximum nominal size of aggregate to be used in concrete may be as large as possible within the limit prescribed by IS $456-2000$.

4)The cement content is to be limited from shrinkage, creeping and cracking

\subsection{Designs for M20 Grade of Concrete}

1)As per IS 456-2000 mix design of M20 grade concrete we have to taken for experimental work.

2)Sieve analysis is done for zone determination so as per IS 383-1970.

3)Condition of exposure is moderate :as per IS 456-2000, page no. 20 Table no. 7 For M20 grade of concrete, minimum cement content $=300 \mathrm{~kg} / \mathrm{m} 3$. Maximum free $\mathrm{W} / \mathrm{C}$ ratio $=0.5$.
4)As cement is OPC is considered.

5) Size of aggregate $=4.76-12.5 \mathrm{~mm}$ (angular).

6) Workability of concrete: The concrete mix proportion chosen should be such that the concrete is of adequate workability for the placing condition of the concrete and can properly be compacted.

7)Degree of workability: medium.

8)Degree of supervision: Good

\section{Sample Calculation for Concrete Mix}

\section{Standard cube are of $0.15 \mathrm{mX0.15mX0.15m}$}

No of cubes $=24$

Mix proportion for M20 grade cement=1:1.5:3

FOR M20 GRADE

For 6 cubes - Control Mix

$6(0.15 \times 0.15 \times 0.15)=0.02025 \mathrm{~m}^{3}$

Assume 50\% Extra for mixing $=0.02025 X 1.5=0.030375 \mathrm{~m}^{3}$

Mix proportion:-1:1.5:3=5.5

Volume of cement $=(0.030375) /(5.5)=5.5227 \times 10^{-3}$

Weight of cement $=5.5227 \times 10^{-3}$ X $1428 \mathrm{~kg} / \mathrm{m}^{3}=7.88 \mathrm{Kg}$

Cement $=7.88=8 \mathrm{~kg}$

Sand $=1.5 \times 8=12 \mathrm{~kg}$

Aggregate $=3$ X 8=24kg

\subsection{FOR $25 \%$ REPLACEMENT (75\%CA+25\% CS)}

For 6 cubes

Cement $=8 \mathrm{~kg}$

Sand $=1.5$ X $8=12 \mathrm{~kg}$

$25 \%$ Coconut Shell = $24 \mathrm{KgX}(25 / 100)=6 \mathrm{~kg}$

Coarse aggregate $=24 \mathrm{~kg}-6 \mathrm{~kg}=18 \mathrm{~kg}$

\subsection{FOR 50\% RESPLACEMENT (50\%CA+50\% CS)}

\section{For 6 cubes}

Cement $=8 \mathrm{~kg}$

Sand $=1.5$ X $8=12 \mathrm{~kg}$

$50 \%$ Coconut Shell $=24 \mathrm{Kg} X(50 / 100)=12 \mathrm{~kg}$

Coarse aggregate $=12 \mathrm{~kg}-12 \mathrm{~kg}=12 \mathrm{~kg}$

$\mathrm{CA}=$ Coarse Aggregate, $\mathrm{CS}=$ Coconut Shells
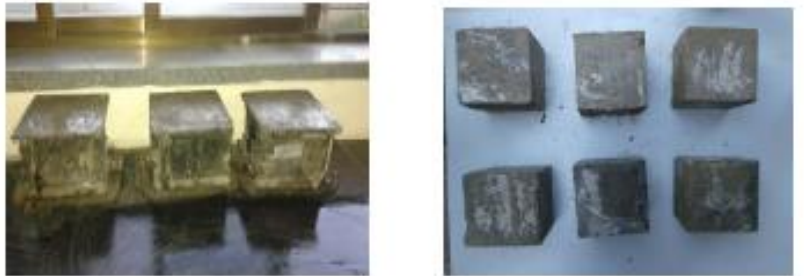

Figure 3: Cube Casting Samples

\section{Compressive Strength Results}

\begin{tabular}{|c|c|c|}
\hline \multirow{2}{*}{ Samples } & \multicolumn{2}{|c|}{ Compressive Strength in Mpa } \\
\cline { 2 - 3 } & 7 Days & 28 Days \\
\hline Control Mix 100\% CA & 14.85 & 21.28 \\
\hline $75 \%$ CA+25\% CS & 13.46 & 20.2 \\
\hline $50 \%$ CA+50\% CS & 13.12 & 19.65 \\
\hline $0 \%$ CA+100\% CS & 9.64 & 14.23 \\
\hline
\end{tabular}




\section{International Journal of Science and Research (IJSR) \\ ISSN (Online): 2319-7064}

Index Copernicus Value (2013): 6.14 | Impact Factor (2014): 5.611

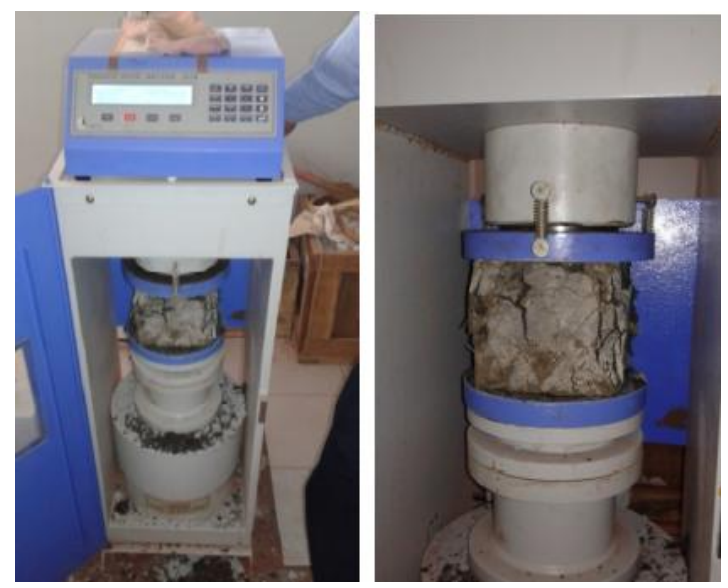

Figure 4: Testing on CTM

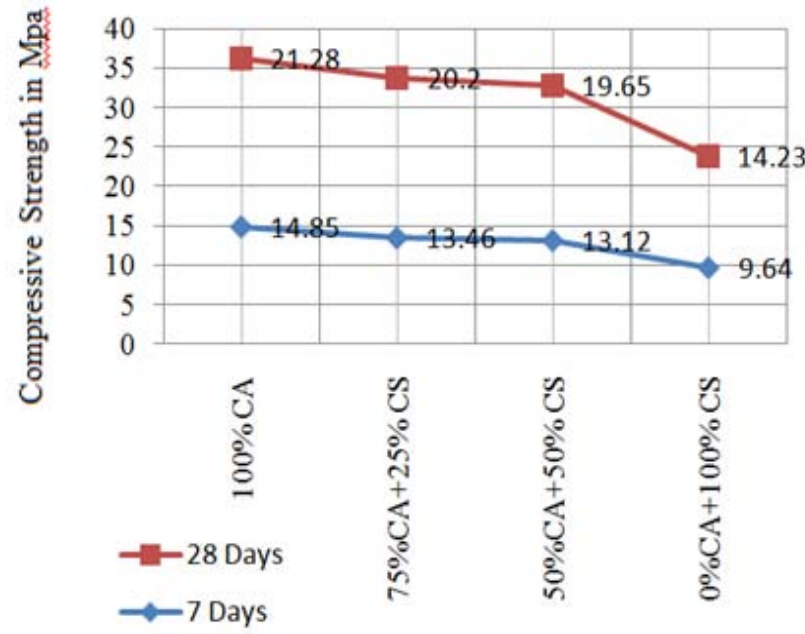

Graph 1: Testing Results

\section{Result Discussion and Conclusion}

Overall cost of construction will reduced. The maximum compressive strength in control mix is $21.28 \mathrm{~N} / \mathrm{mm}^{2}$ at 28 days, while the minimum strength at same days is 14.23 $\mathrm{N} / \mathrm{mm}^{2}$. Thus compressive strength decreased as percentage of coconut shell is increased. Therefore coconut shell can be used where light weight concrete is required. Proper bonding between coconut shell and cement is not possible because of surface area of coconut shell aggregate.[13] In future, we can increase strength of coconut shell concrete by adding admixtures.

\section{References}

[1] S Ghosal, SC Moulik, "Use of Coconut Shell as an Aggregate in Concrete: a Review," International Journal of Scientific Engineering and Technology ISSN :2277-1581 Volume No.4 Issue No.9, pp: 476-477

[2] Damre Shraddhal, Firake Hitali, Dode Pradeep and Shrikant Varpe, "Sustanable concrete by partially replacing coarse aggregate using coconut shell", Journal of today's Ideas ,Tomorrow Technology, vol 2 No. 1, June 2015, PP 1-14

[3] Devanshu Ahlawat, L. G. Kalulkar, "Coconut shell as a partial replacement of coarse aggregate in concrete",
IOSR, journal of Mechanical and civil engineering, eISSN-2278-1684, pp 61-64

[4] Vishwas P. Kulkarni, Sanjay kumar B. Gaikwad, "Comparative study on coconut shell aggregate with conventional concrete", IJIET, Volume 2, Issue 12, June 2013, pp 67-70

[5] Tomas U. Ganiron Jr, "Sustainable Management of Waste Coconut Shells as Aggregates in Concrete Mixture", Journal of Engineering Science and Technology Review 6 (5) (2013) 7-14

[6] Amaranth Yerramala, Ramchandrudu C, " Propertise of concrete with coconut shell as Aggregate replacement", ISSN: 2278-7461, www.ijeijournal.com Volume 1, Issue 6 (October2012) PP: 21-31

[7] Cordilia Marboh, Amrita agnihotri, Rajani, Raja Tomar, Rahulkumar stabhaiya, "Behaviour of reinforced concrete beam with coconut shell as a coarse aggregate", IJEMMR, Vol. 1, Issue 6, June 2015

[8] K. Gunasekran, R. Annadurai, P. S. Kumar, "Long term study on compressive and bond strength of coconut shell aggregate concrete", Construction and building materials, 28(2012)208-2015, www.elsevier.com

[9] E.A. Olanipekun, K.O. Olusola, O. Ata, “A Comparative study of concrete properties using coconut shell and palm kernel shell as coarse agreegate", Building and enivironment 41 (2006), 297-301, www.elsevier.com

[10] Manindar Kaur, Manpreet Kaur, “ A Review on utilization of coconut shell as coarse aggregate in mass concrete", IJAER, Vol 7, No. 11, (2012)

[11] Parag S. Kambli, Sandya r. Madhapati, "Application of coconut shell as a coarse aggregate in concrete : A technical review", IJERA, Volume 4 ,Issue 3 (version 1), March 2014, pp. 498-501.

\section{Author Profile}

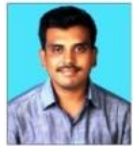

Yogesh Narayan Sonawane, received the M.Tech. degree in Structural engineering from Sardar Vallabhbhai National Institute of Technology, Surat, in 2010. Now he is working as an assistant professor in civil engineering department, at R. C. Patel Institute of Technology, Shirpur

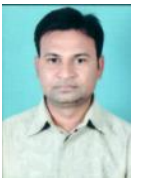

Chetan Jaiprakash Chitte, received the M.Tech. degree in Structural Dynamics \& Earthquake Engineering from VNIT Nagpur, in 2006. Now he is working as an assistant professor in civil engineering department, at R. C. Patel Institute of Technology,

Shirpur 